\title{
VERTEBROPLASTY IN THE TREATMENT OF VERTEBRAL FRACTURES CAUSED BY PLASMACYTOMA
}

\author{
Vjekoslav Kolarević ${ }^{1}$, Ivan Vidaković ${ }^{2}$ Marko Šutalo ${ }^{3}$, Vjeran Rapan ${ }^{3}$, \\ Domagoj Rapan ${ }^{3}$ and Saša Rapan ${ }^{3}$ \\ ${ }^{1}$ Department of Orthopedics, Faculty of Medicine, Josip Juraj Strossmayer University of Osijek, Osijek, Croatia; \\ ${ }^{2}$ One Health Group, Sheffield, United Kingdom; \\ ${ }^{3}$ Faculty of Medicine, Josip Juraj Strossmayer University of Osijek, Osijek, Croatia
}

\begin{abstract}
SUMMARY - The aim of this study was to compare and evaluate clinical results before and after vertebroplasty in the treatment of myeloma-induced vertebral fractures. Success of the surgery was defined by increased or reduced pain intensity before and after the treatment, as assessed using the visual analog scale (VAS). The study was designed as a retrospective-prospective study. The study included 26 patients, 14 women and 12 men. Data on patients treated for myeloma-induced vertebral fractures were collected at the Department of Orthopedics, Osijek University Hospital Centre. The following data were analyzed: gender, duration of illness, intensity of pain before and after treatment (using VAS), radiological changes before and after treatment, grade of vertebral fracture, and extracorporeal cement leakage from the vertebral body to the surrounding tissue during the procedure. Difference in pain intensity before and after the surgery was statistically significant. All patients complained of pain before the surgery (pain intensity median 8), whereas after the surgery, pain intensity decreased in all patients (pain intensity median 2). In conclusion, improvement in clinical results of the treatment of myeloma-induced vertebral fractures with vertebroplasty proved to be significant.
\end{abstract}

Key words: Vertebroplasty; Spinal fractures; Plasmacytoma; Croatia

\section{Introduction}

Vertebroplasty as a minimally invasive surgical procedure for treatment of vertebral body compression fractures due to osteoporosis, secondary tumors and multiple myeloma contributes to significant pain reduction and improved quality of life $^{1}$. Most patients with myeloma have both diffuse and localized involvement of bone tissue in myeloma cells. In addition, the cytokine-mediated imbalance of the osteoclastic (bone resorption) and osteoblastic (reconstruction) function leads to systemic osteoporosis and spontaneous fractures $\mathrm{s}^{2,3}$.

Correspondence to: Saša Rapan, Faculty of Medicine, Josip Juraj Strossmayer University of Osijek, Cara Hadrijana 10E, HR-31000 Osijek, Croatia

E-mail: sasa.rapan@gmail.com

Received October 6, 2017, accepted October 10, 2017
Although vertebroplasty has been widely used since 1984, there are no major studies related to the effect of this surgical method with regard to plasmacytoma, which is not the case when it comes to osteoporotic fractures.

The aim of this prospective-retrospective study was to examine the success of vertebroplasty as a surgical method in the treatment of pathologic fractures of the vertebrae, by comparing the patient clinical picture before and after surgical procedure. Success was defined by reduction in pain intensity measured before and after the procedure using the visual analog scale (VAS).

\section{Patients and Methods}

For the purpose of the research, we collected history data on patients with plasmacytoma treated with 

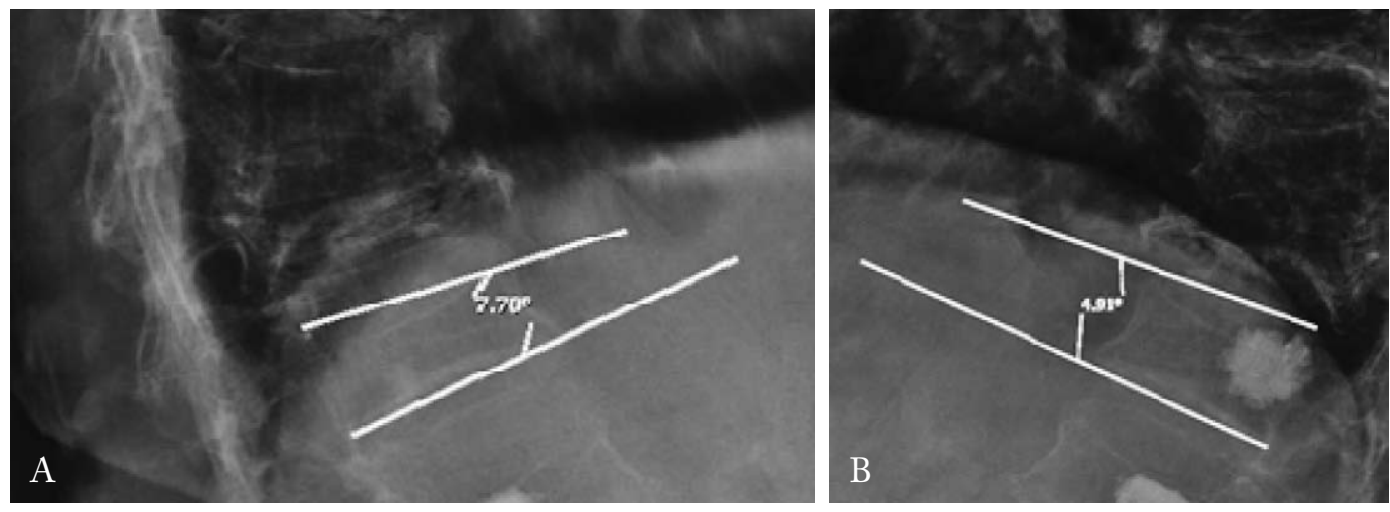

Fig. 1. Wedge angle before (A) and after (B) vertebroplasty.

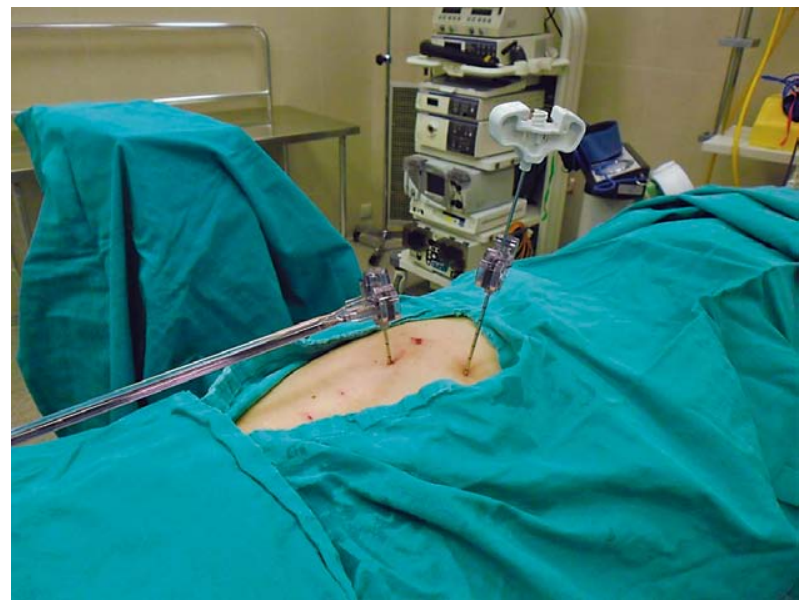

Fig. 2. Bone biopsy.

vertebroplasty at the Department of Orthopedics, Osijek University Hospital Centre in the last ten years. Based on the medical documentation available, the following general data were analyzed: gender, duration of the illness, level of pain before and after the surgery (VAS), radiological changes in the operated segment before and after the procedure, especially the grade of fracture, and existence of extracorporeal leakage of cement during the procedure. VAS is the most commonly used scale for measuring pain intensity. Patients filled out a questionnaire immediately before the procedure and three weeks after it. Vertebral body angle of inclination was measured before and after the procedure by latero-lateral radiograph (Fig. 1).

All patients underwent vertebroplasty. The patient was placed in a prone position (significant kyphosis correction was achieved and the height of the collapsed vertebral body was increased by up to $10 \%)$. The fractured vertebra was located with an image intensi-

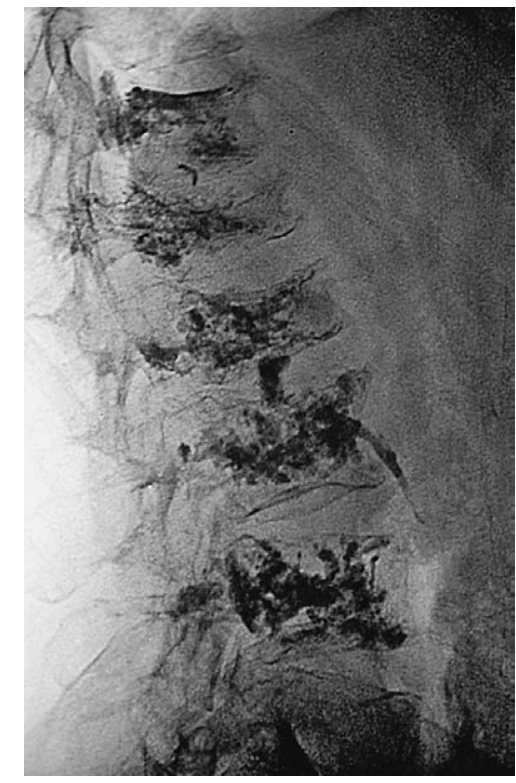

Fig. 3. Postoperative $x$-ray.

fier and the operative field was prepared and covered. If the procedure was performed under local anesthesia, skin and subcutaneous tissue to the periosteum were anesthetized with $2 \%$ lidocaine. If the patient could not tolerate pain, the procedure was performed under general anesthesia. The 11-gauge bone biopsy needle was placed in the anterior third of the vertebral body. The procedure could be unipedicular or bipedicular. When the needle position was satisfactory, a separate thin needle for vertebral body biopsy, included in the vertebroplasty kit, was placed in the vertebral body through the previously inserted needle. The material obtained was sent for histopathologic analysis (Fig. 2).

After that, bone cement of appropriate viscosity was applied to the vertebral body. It was very impor- 
tant to control the procedure with an image intensifier to avoid leakage of the cement and various resulting complications. The cement was applied until its position in the last quarter of the vertebral body was satisfactory, or until the occurrence of epidural, intravenous or intradiscal cement extravasation (Fig. 3).

With $15 \%$ of vertebral body filled with cement (approximately $3.5 \mathrm{~mL}$ ), satisfactory strength of the broken vertebral body was achieved. In all the procedures analyzed, high-viscosity cement was used (Confidence, De Puy, Raynham, Massachusetts, USA). The patient remained on bed rest for at least one hour, and was discharged 24 hours after the procedure ${ }^{4}$. Three weeks after the procedure, during the first follow-up examination scheduled to obtain histopathologic findings, the patients filled out the questionnaire again.

\section{Statistical analysis}

Categorical data were represented by absolute frequencies. Gender-based differences in fracture classification were tested using Fisher exact test. Numerical data were described by median and limits of interquartile range. Normal distribution of numerical variables was tested by Shapiro-Wilk test. Differences in VAS assessed pain intensity before and after the surgery were tested by Wilcoxon test ${ }^{5}$. All $\mathrm{p}$ values were twosided. The level of significance was set at Alpha=0.05. For statistical analysis, the MedCalc Statistical, software version 14.12.0 (MedCalc Software BV, Ostend, Belgium; 2014) statistical program was used.

\section{Results}

The research was conducted on 26 patients having undergone vertebroplasty procedure for pathologic vertebral body fracture due to the primary disease, plasmacytoma; there were 12 male and 14 female patients. Most of the patients, six of them, sustained TH11,TH12 and L1 fractures; two patients sustained TH6 and TH10 fractures; L2 and L3 were fractured in five patients; L3 was fractured in three patients, and only one patient had TH7 vertebral body fracture. Two fractured vertebrae were found in ten patients.

According to the Genant classification of vertebral fractures ${ }^{6}$, depending on whether the fracture was complete or not, the patients were divided into three fracture grades: nine patients had fractures where 25\% of the vertebral body height was collapsed, thirteen pa-
Table 1. Fracture classification (Gęnant) by gender

\begin{tabular}{|l|l|l|l|l|}
\hline \multirow{2}{*}{} & \multicolumn{3}{|c|}{ Number of patients } & \multirow{2}{*}{$\mathrm{p}^{*}$} \\
\cline { 2 - 4 } & Men & Women & Total & \\
\hline $\begin{array}{l}\text { Grade I } \\
\text { (collapse up to 25\% } \\
\text { of vertebral body } \\
\text { height) }\end{array}$ & $6 / 12$ & $3 / 14$ & $9 / 26$ & \\
\hline $\begin{array}{l}\text { Grade II } \\
\text { (collapse from 26\% } \\
\text { to 40\% of vertebral } \\
\text { body height) }\end{array}$ & $5 / 12$ & $8 / 14$ & $13 / 26$ & 0.37 \\
\hline $\begin{array}{l}\text { Grade III } \\
\text { (collapse more than } \\
\text { 40\% of vertebral } \\
\text { body height) }\end{array}$ & $1 / 12$ & $3 / 14$ & $4 / 26$ & \\
\hline Total & $12 / 12$ & $14 / 14$ & $26 / 26$ & \\
\hline
\end{tabular}

*Fisher exact test

Table 2. Assessment of pain intensity before and after surgery using visual analog scale (VAS)

\begin{tabular}{|l|l|l|l|}
\hline \multirow{2}{*}{} & \multicolumn{2}{|c|}{ Median (interquartile range) } & \multirow{2}{*}{$\mathrm{p}^{*}$} \\
\cline { 2 - 4 } & Before surgery & After surgery & \\
\hline VAS & $8(7-9)$ & $2(1.75-3)$ & $<0.001$ \\
\hline
\end{tabular}

*Wilcoxon test

tients had $26 \%$ to $40 \%$ of the height of the vertebral body collapsed, and four patients had more than $40 \%$ of the vertebral body height collapsed. There were no significant gender differences in fracture classification (Table 1).

Before and after the surgery, the patients evaluated pain intensity using the VAS. There was significant postoperative reduction (75\%), median 2 (interquartile range 1.75-3), ranging from 1 to 4 , compared to presurgery period (Wilcoxon test, $\mathrm{p}<0.001$ ) (Table 2).

During the procedure, cement leakage occurred in eight (30.7\%) patients.

After vertebroplasty, we noticed minor correction of the angle of inclination of the fractured vertebral body (Fig. 4).

\section{Discussion}

This research has revealed that there are very few reports on the efficiency and safety of using vertebro- 


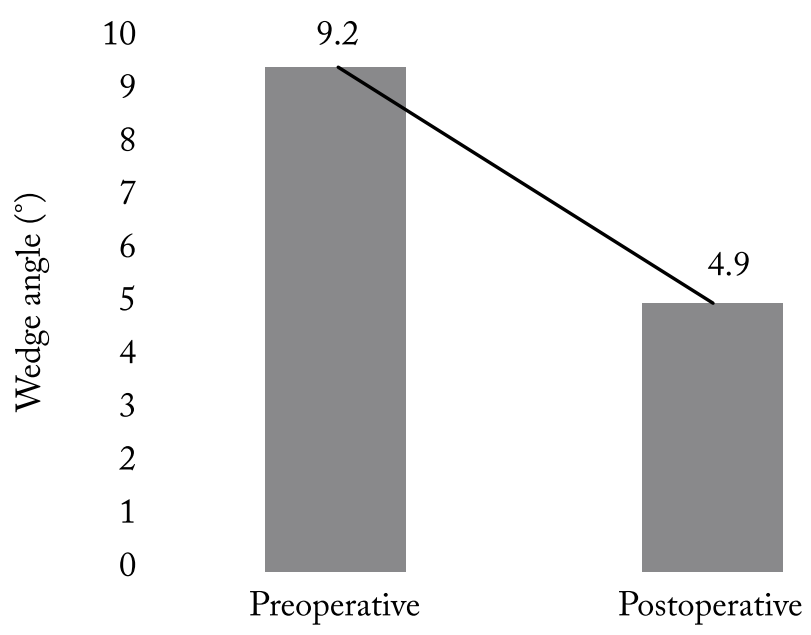

Fig. 4. Wedge angle before and after vertebroplasty.

plasty in treating plasmacytoma-induced vertebral fractures. Furthermore, all such reports are limited by the number of patients and the results reported.

Our analysis demonstrated that vertebroplasty enabled direct reduction of pain intensity immediately and three weeks following the procedure. This pain reduction was not only clinically significant (i.e. change from score 8.0 to 2.0 on the VAS, which is equivalent to $75 \%$ reduction $)^{7}$, but it also was very beneficial because most patients experienced intense pain that could not be relieved by analgesics or conventional medical therapy ${ }^{8}$. When analyzing the quality of life before and after vertebroplasty, Rapan et al. ${ }^{9}$ found that as many as $91.8 \%$ of patients were satisfied with their postoperative status, and that the same number of patients would be willing to repeat the procedure in the event of a repeated fracture.

The mechanism of pain reduction has so far been based on the assumption of stabilization of painful fragments and thermal effect occurring during polymerization of cement, which would essentially cauterize nerve endings ${ }^{10}$. Khan et al. ${ }^{11}$ found similarities in the success of treating vertebral fractures caused by osteoporosis and those caused by plasmacytoma.

Teng et al. ${ }^{12}$ proved that, following vertebroplasty, the angle of deformity improved significantly, both in the entire spinal column and in the vertebral wedge (7.4 degrees). In our research, we also found improvement of the wedge angle ( 4.3 degrees), but not to the extent indicated by the authors mentioned above.

In terms of safety, it seems that vertebroplasty is a safe procedure. Although vertebroplasty was per- formed under local anesthesia in our case, the patients tolerated it well and we had no serious complications such as pulmonary embolism or infection to report.

Cement leakage occurred in approximately 30.7\% of all treated levels. Leakage was asymptomatic in all cases. Results indicated that about $10 \%$ of the patients would develop new changes in their spine within two years following the treatment. It seems that the development of new spinal fractures is more frequent (occurs almost twice as often) in patients with multiple myeloma than in metastases. This is no surprise considering the fact that there are several studies indicating that patients suffering from plasmacytoma are more sensitive to fractures ${ }^{13-16}$. Generally speaking, data indicate that the frequency of new fractures after vertebroplasty intervention is no greater than the spontaneous occurrence of new spinal fractures (19\%24\%) reported in patients who had not been previously treated ${ }^{17}$.

At present, there is an obvious lack of studies that would draw comparisons between kyphoplasty and other interventions, both invasive and noninvasive. Current results indicate that kyphoplasty and vertebroplasty provide similar reduction of pain intensity, but that kyphoplasty is also linked to a lower rate of cement leakage, as evident in other studies ${ }^{10,16-18}$. Also, in cases where high-viscosity cement was used as opposed to low-viscosity cement in osteoporotic fractures, there was a significantly lower rate of cement leakage ${ }^{19}$.

When compared to previous studies in our group and to other studies aimed at evaluating the efficiency of vertebroplasty in benign osteoporotic fractures, we found similar but yet not identical short-term and long-term outcomes. Specifically, our analysis at treatment level was very similar to previous studies of benign compressive fractures in terms of distribution ${ }^{5}$, suggesting that the prevalence/level of symptomatic compression fractures in patients with plasmacytoma is no different from that in osteoporotic patients with painful fractures. Certain limitations that apply to this study could be attributed to the nature of retrospective studies as such, small number of patients and short period of observation.

\section{Conclusion}

Based on the research conducted and the results obtained, the following conclusions can be drawn: 
- After vertebroplasty, pain in the area of fractured vertebrae was significantly reduced.

- In eight (30.7\%) patients, cement leakage occurred during surgery, which did not affect the success of the procedure.

- Vertebroplasty increases the height of the fractured vertebra and reduces the wedge angles.

- Vertebroplasty (with high-viscosity cement) is an efficient and safe method of treatment of vertebral body fractures caused by plasmacytoma.

\section{References}

1. Gangi A, Guth S, Imbert JP, et al. Percutaneous vertebroplasty: indications, technique, and results. Radiographics. 2003 MarApr;23(2):e10. DOI: 10.1148/rg.e10

2. Kulkarni RS, Parikh SK, Anand AS, Panchal HP, Patel AA, Trivedi $\mathrm{P}$, et al. Solitary plasmacytoma of bone involving spine in a 12-year-old boy: report of a rare case and review of literature. J Pediatr Neurosci. 2017;12(1):67-71. DOI: 10.4103/jpn. JPN_153_16

3. Vrhovac B, Jakšić B, Reiner Ž, Vucelić B. Interna medicina. $4^{\text {th }}$ edn. Zagreb: Naklada Ljevak; 2008. (in Croatian)

4. Rapan S, Jovanović S, Gulan G, Boschi V. Vertebroplastika. Medicina Fluminensis. 2011;47(1):29-36. (in Croatian). Hrčak ID: 66093

5. Trout AT, Gray LA, Kallmes DF. Vertebroplasty in the inpatient population. AJNR Am J Neuroradiol. 2005;26:1629-33. PMID: 16091505

6. Baum T, Bauer JS, Klinder T, Dobritz M, Rummeny EJ, Noël $\mathrm{PB}$, et al. Automatic detection of osteoporotic vertebral fractures in routine thoracic and abdominal MDCT. Eur Radiol. 2014;24(4):872-80. DOI: 10.1007/s00330-013-3089-2

7. Dworkin RH, Turk DC, Wyrwich KW, Beaton D, Cleeland CS, Farrar JT, Haythornthwaite JA, Jensen MP, Kerns RD, Ader DN, Brandenburg N, Burke LB, Cella D, Chandler J, Cowan P, Dimitrova R, Dionne R, Hertz S, Jadad AR, Katz NP, Kehlet H, Kramer LD, Manning DC, McCormick C, McDermott MP, McQuay HJ, Patel S, Porter L, Quessy S, Rappaport BA, Rauschkolb C, Revicki DA, Rothman M, Schmader KE, Stacey BR, Stauffer JW, von Stein T, White RE, Witter J, Zavisic S. Interpreting the clinical importance of treatment outcomes in chronic pain clinical trials: IMMPACT recommendations. J Pain. 2008;9:105-21. DOI: 10.1016/j.jpain. 2007.09.005
8. Health Quality Ontario. Vertebral augmentation involving vertebroplasty or kyphoplasty for cancer-related vertebral compression Fractures: a systematic review. Ont Health Technol Assess Ser. 2016;16(11):1-202. PMCID: PMC4902848

9. Rapan S, Batrnek J, Rapan V, Biuk E, Rapan D. Quality of life in patients following vertebroplasty. Open Access Maced J Med Sci. 2017 Feb 15; 5(1): 42-47. DOI: 10.3889/oamjms.2017.018

10. Hulme PA, Krebs J, Ferguson SJ, Berlemann U. Vertebroplasty and kyphoplasty: a systematic review of 69 clinical studies. Spine. 2006;31(17):1983-2001. DOI: 10.1097/01.brs.000022 9254.89952.6b

11. Khan OA1, Brinjikji W, Kallmes DF. Vertebral augmentation in patients with multiple myeloma: a pooled analysis of published case series. AJNR Am J Neuroradiol. 2014;35(1):20710. DOI: 10.3174 /ajnr.A3622

12. Teng MM, Wei CJ, Wei LC, Luo CB, Lirng JF, Chang FC, Liu CL, Chang CY. Kyphosis correction and height restoration effects of percutaneous vertebroplasty. AJNR Am J Neuroradiol. 2003 Oct;24(9):1893-900. PMID: 14561624

13. Melton LJ, Kyle RA, Achenbach SJ, Oberg Al, Rajkumar SV. Fracture risk with multiple myeloma: a population-based study. J Bone Miner Res. 2005;20:487-93. DOI: 10.1359/JBMR. 041131

14. Bouza C, López T, Magro A, Navalpotro L, Amate JM. Efficacy and safety of balloon kyphoplasty in the treatment of vertebral compression fractures: a systematic review. Eur Spine J. 2006;15:1050-67. DOI: 10.1007/s00586-005-0048-x

15. Taylor RS, Fritzell P, Taylor RJ. Balloon kyphoplasty in the management of vertebral compression fractures: an updated systematic review and meta-analysis. Eur Spine J.2007;16:1085100. DOI: $10.1007 / \mathrm{s} 00586-007-0308-z$

16. Eck JC, Nachtigall D, Humphreys SC, Hodges SD. Comparison of vertebroplasty and balloon kyphoplasty for treatment of vertebral compression fractures: a meta-analysis of the literature. Spine J. 2008;8:488-97. DOI: 10.1016/j.spinee.2007. 04.004

17. Lindsay R, Silverman SL, Cooper C. Risk of new vertebral fracture in the year following a fracture. JAMA. 2001;285: 320-3. DOI: $10.1001 /$ jama.285.3.320

18. Taylor RS, Taylor RJ, Fritzell P. Balloon kyphoplasty and vertebroplasty for vertebral compression fractures: a comparative systematic review of efficacy and safety. Spine. 2006;31:27472755. DOI: 10.1097/01.brs.0000244639.71656.7d

19. Rapan S, Jovanović S, Gulan G, Boschi V, Kolarević V, Đapić T. Vertebroplasty - high viscosity cement versus low viscosity cement. Coll Antropol. 2010;34(3):1063-7. Hrčak ID: 59375 


\section{Sažetak}

\section{VERTEBROPLASTIKA U LIJEČENJU PLAZMACITOMA}

\section{Kolarević, I. Vidaković, M. Šutalo, V. Rapan, D. Rapan i S. Rapan}

Cilj rada bio je ispitati uspješnost operacijske metode vertebroplastike u liječenju patološkog prijeloma trupa kralješka, i to usporedbom kliničke slike prije i nakon operacijskog zahvata. Uspješnost se definirala smanjenjem ili povećanjem intenziteta boli pomoću ljestvice VAS prije i nakon operacijskog zahvata. Istraživanje je provedeno kao retrospektivno-prospektivna studija, a obuhvatilo je 26 bolesnika, od toga 14 žena i 12 muškaraca. Iz medicinske dokumentacije Zavoda za ortopediju KBC-a Osijek prikupljeni su podatci o bolesnicima koji su liječeni vertebroplastikom zbog prijeloma kralješka uslijed plasmacitoma. Analizirani su sljedeći podatci: spol, dužina trajanja tegoba, razina bolova prije i poslije operacije (pomoću ljestvice VAS) te radiološke promjene na operiranom segmentu prije i poslije zahvata, naročito stupanj prijeloma te postojanje ekstrakorporalnog istjecanja cementa tijekom zahvata. Zabilježene su statistički značajne razlike u bolovima prije i nakon obavljene vertebroplastike koje su govorile u prilog uspješnosti operativnog zahvata. Svi bolesnici su osjećali bolove prije operacije (medijan 8, interkvartilni raspon 7-9), dok je prisutnost boli značajno smanjena nakon operacije kod svih bolesnika (medijan 2, interkvartilni raspon 1,75-3). Rezultati su pokazali statistički značajno poboljšanje kliničke slike nakon primjene vertebroplastike u liječenju prijeloma kralješka uslijed plasmacitoma.

Ključne riječi: Vertebroplasika; Kralježnica, prijelomi; Plazmocitom; Hrvatska 